\title{
TIBETAN LANDSCAPES IN CHUKOTKA: THE CONSUMPTION OF ESOTERIC MASS PRODUCTION IN THE COMMUNITY OF MARKOVO VILLAGE
}

\author{
Marina Hakkarainen
}

\begin{abstract}
Two opposite worlds are represented in the traditionalistic discourse about the Markovo village of Chukotka: the traditional world of the older generation, and the modern world of the young people. While elders are regarded as keepers of indigenous knowledge and shamanic powers, it is thought that youngsters who are living in the present-day urbanized village have lost connection with all these things. This juxtaposition is strongly expressed in the healing narratives of the villagers. However, young people are learning their local healing tradition, at the same time using modern 'esoteric' practices. They also practice the traditional ways of receiving knowledge (in dreams) while assimilating modern mass media information. It is here that the two worlds meet, and the article shows how the villagers overcome this contradiction and maintain equilibrium between the old and the new.
\end{abstract}

Key words: Chukotka, Chuvans, dreams, 'esoteric' practices, mass production, shamans, traditional healing.

\section{INTRODUCTION}

In 1998 and 1999 I visited the Markovo village in Chukotka while doing my post-graduate research in ethnography. ${ }^{1}$ My task was to collect data about health care among the local people. Before the trip I carefully read descriptions of the community (e.g., Dyachkov 1992 [1893], Olsufev 1896: 73-74, Silnitski 1897: 22, Sokolnikov 1911, Merker 1998: 62) and went there with expectations of something exotic and attractive: people who live in Russian peasant log huts, sing Russian folk songs, tell Russian fairy tales, and wear long dresses sarafans at village events. At the same time, I believed them "spiritually close to the first inhabitants of the area" (Tugolukov 1975: 184), the Siberian peoples, which is why some researchers have attributed them shamanic qualities (see Batyanova 2005). Thus I was going to find so far from home a healing tradition, be it Old Russian or indigenous. ${ }^{2}$ 
The attractive picture disappeared as soon as I reached the village. ${ }^{3}$ Markovo was an 'urban-type settlement' (poselok gorodskogo tipa) with multi-storied and one-storied houses occupied by several families. About 1,200 people lived in the village; altogether 400 persons were registered as indigenous inhabitants: they were Russian-speaking descendants of both of the native peoples in this area (the Even, the Chukchi, the Chuvan, the Koryak), and of early Russian colonists. The majority of the adult population was working at 'urbantype' enterprises, in communal services, school, airport, bank, hospital, etc., but hunting, fishing and cultivating vegetables also formed an important part of their domestic economy. People lived in apartments with standard urban interiors, where television sets and other items of the "civilized world" occupied a significant place. In many respects, the villagers of Markovo tried to maintain an urban lifestyle, they were involved in the consumption of mass material and cultural products, as are many peoples in Russia. The so-called 'esoteric' mass production was also familiar to them.

In this article I am going to discuss to two women's stories about their dreams and healing practices. Here I wish to demonstrate how widely spread was the 'esoteric discourse' used by these women, how the material of mass media is becoming to be incorporated into the production of local knowledge connected with the power of healing, and how it is intermingled with or, conversely, how it diverges from the 'traditional' representations of the Markovo community. ${ }^{4}$ Finally, I will discuss how this contemporary discourse is integrated in the local culture and the whole picture of indigenous society: that is, how it became a part which "invests" this picture "with internal consistency and coherent conceptual structure" (Basso 1996: 61), as I had the chance to witness during the recorded interviews and during my visits.

\section{'MODERNITY VERSUS TRADITION': THE YOUNG IN MARKOVO}

It is not an exaggeration to say that 'traditionalization' and 'indiginization' of localities are the marks of our time (e.g., Appadurai 1996: 32). People in Markovo were also involved in the discussion about their tradition and indigenous cultures of peoples of the North (see, e.g., Pentikäinen 1997a,b). They stressed that there was a break between the traditional past and the modern present. They also complained that tradition was lost, and wished to find it anew. In this situation my interest in tradition and traditional healing was readily understood by the people. Both men and women talked about local healing: their own and their parents' everyday use of herbs and materia medica (Latin 'medical substance'), the medical practices of specific healers, and the knowledge of 
shamans. The respondents from Markovo usually finished their explanations concluding that the village now lived in a modern way and the indigenous healing tradition, in particular, belonged to the elders and had disappeared with them.

The concept of the elders did not become clear enough for me at once owing to its varied nature. Where did the elders exist in the multi-dimensional social space of the Markovo community? Were they the people of the past? Or were they just aged members of the community of the $1960 \mathrm{~s}$ - there were a few of them in the village at that time of my visit. Maybe they were the generation of parents related to the generation of children? Or perhaps they were old people (dead by now/lived in the past) acting on the border of our world and the other world? All these meanings were exploited by the people of Markovo in conversations and interviews. The role of elders, however, was clear enough. For the people of Markovo, the elders played the role of keepers of tradition. Their knowledge was associated with the knowledge of the indigenous people of the region. The elders understood the environment and the natural conditions, and they knew how to behave properly in dangerous places inhabited by spirits. Their clothes and nutrition corresponded with the local circumstances much better. They spoke the local languages and were involved in relationships with all the indigenous groups of the territory. Of course, they knew the local tradition of healing. They were experts in human relations, and this knowledge gave them strength to treat illnesses by solving conflicts. ${ }^{5}$ Some elders - as local people knew - had shamanic abilities. They were 'strong' people. The last person of this kind, who was 'strong' and could be regarded as a real shaman, died about twenty years ago. All these stories reminded me the ethnographic research of Sokolnikov, who described in detail the medical practices in Markovo a hundred years ago. He also wrote that some village shamans had been alive several years ago, but by then all of them had been dead or had stopped practicing (Sokolnikov 1911: 77). All these talks, conversations and discussions confirm that 'strong' elders and shamans were already a thing of the past.

The young had another position in the community in the discourse about tradition and healing in Markovo. They were people who did not understand the indigenous tradition and the traditional knowledge of their elders for many reasons. These young people were blamed because they showed no interest in the life of their parents and ancestors, and were oriented to modern values and civilization instead. Also, the elders regarded their own knowledge useless for the new generations. This is why they preferred not to transmit the knowledge, and took their secrets with them. Moreover, the sacred knowledge, which includes healing, had to remain secret for the children - this is why children were always kept at distance from the scene of healing rituals. The young 
were "blind" to such things. It became quite clear to me who the youngsters were - they lived in the urban-type village and had accepted the modern way of life. There was a crucial distance between them and the elders: the elders 'knew' and the young people 'did not know'. The title 'the youngsters' did not much correspond to their age. ${ }^{6}$

The opposition between 'the past / elders' / indigenous tradition / knowledge' and 'the present / youngsters / modern life / ignorance' was very important in the conceptualization of an indigenous community, because the discursive representation of an indigenous community was constituted as a dynamic model of the interaction between four generations: the opposition of the elders and the youngsters with children and adults (the latter are not clearly conceptualized as a separate generation) remaining between them. This opposition was also important in relation with the indigenous knowledge - the knowledge can be accumulated in the course of life (youngsters became elders), and it dissimilates during the process of children growing up - that is, children come to the world equipped with knowledge. The idea of rebirth of dead elders into children ties the generations into a full circle of life. As I understood, the local people had as if a permission to be "blind" to the tradition and open to influences of the modern world at their young age. At the same time, the tensions between the elders and youngsters presume dynamics of overcoming the gap of ignorance in tradition by the young by becoming adult and joining the traditional world (Hakkarainen 2004). So within years the youngsters learned their tradition, they had accumulated traditional knowledge and strength, and on the border between the worlds of the dead and the living they became elders and then shamans. ${ }^{7}$

Thus the two severed worlds coexisted in the discourse on Markovo healing tradition during my visit there in 1998-1999: the indigenous and traditional world belonged to the elders and shamans of the past, while the world of the young generation was set in the contemporary society without the indigenous tradition. In the meantime, outside these discussions and talks, the village led its ordinary everyday life. This was a traditionalistic context for the stories about healing and dreams that were narrated to me by two village women.

\section{WOMEN'S HEALING PRACTICES}

The so-called 'esoteric' literature has been widely replicated in mass culture production all over Russia in the $1990 \mathrm{~s}$, featuring a mixture of ideas from different religious traditions like Buddhism, Christianity, Islam, shamanism and spiritual movements and doctrines like theosophy, anthroposophy, etc., in 
their generalized and popular versions. In the same context one can come across references to tradition as such. Many healers, especially in urban communities, exploit this fact in order to attract patients (e.g., Lindquist 2004, 2006).

The women of Markovo were not beyond the process of appropriation of these models of healing, which were new for them. One of my informants, Antonina $^{8}$ (born in 1959), told me about this time:

[W] hen all these Dyunas ${ }^{9}$ popped up, [people] started to study all these [practices]. Because it was interesting. Everybody tests this on him- or herself. We tested this on ourselves [...] [I] healed with hands [...].

This marked the beginning of her interest towards healing in her early thirties.

Visions, card divinations, and communication with spirits by means of spirit boards or plate lifting and other ways of 'playing with magic', mixing curiosity, fear and amusement, are familiar to Markovo women from childhood as a part of children and teenage culture, which was spread widely throughout Russia (see Cherednikova 2002, also Lurie 1992, Toporkov 1992, Urvantseva 2005). I was convinced of it after spending an evening with a schoolgirl and her older friend, ${ }^{10}$ who told me about their 'magic games' and laughed at these out loud. Will they begin to take it more seriously in time?11

Antonina told about 'the séances' and other experiments (such as healing "with hands and listening", based on the use of "bio-energy") with a tongue in cheek:

Oh, what haven't we come up with; all odds and ends did we invent [...] This healing. And in newspapers [...] what haven't we read about [...] everything we did. All of a sudden we started to summon spirits [...] 'Come here, Eugenii Petrovich, come to me, heal me...'

But then she seriously continued that she felt "as if being asleep" during this séance, she had heard someone coming, a gust of wind, and sensed somebody sitting on the chair. The emotional switch from a story about a funny game to a tale about things important to her was very fast and thus almost unnoticeable. These experiments, as she said, concluded with an unfortunate result: she became gravely ill and, as a result, stopped carrying out these experiments. However, she still has her special ability to see future and other invisible things. She believed that she had got it from her mother, a "coastal Chukchi woman".

Antonina did not practice experimental healing alone. Her friend, Nina (born in 1960), was also involved in it. Nina preferred to explain her healing experi- 
ence in different terms. She described in detail how she cured her children and herself in acute cases, when she believed that official medicine was not useful. The first time when it happened she decided to "peek in" her baby's dream; the stimulus for it was a film about dreams: "Just then we were reading books [...] about mystical incidents [...] And right at this time there was this film about dreaming. Do you remember it?" (I did not). Then she saw "a small creature with small legs like Nutcracker (Shchelkunchik), but more terrible," who had troubled her daughter.

In reality, as she told me, she did not possess and use her own knowledge but addressed her dead ancestors: "It happens that I am calling out to those who can help me, and my own elders too. Because there is a connection between people..." Her dead ancestors, who are of Koryak and Chukchi origin, gave her knowledge, which she has not got from her living parents. The ancestors were keepers of healing rites, and these rites were spontaneously transmitted to her in circumstances of strong emotional tension. Later she could not remember these exactly. In her opinion, Nina possessed some special abilities, though only on the 'genic' level. The ancestors-shamans gave her strength, and she could turn to them every time she needed. Her healing experience was not restricted to these cases (for example, she knew very well the techniques of removing the influence of evil eye or other things) these particular instances of healing were emphasized.

Although these two women operated with terms such as 'bio-field' or 'bioenergy', their conceptualization of healing was, in my opinion, intrinsically specific to the Markovo tradition: in serious cases of illness many indigenous inhabitants of Markovo, whom I interviewed, had their own traditional resource - the help of their recently departed elders and shamans. The latter could share their ancestral knowledge, power or skills during their visiting the living in their sleep or a similar state. ${ }^{12}$

It should be mentioned here that notwithstanding the degree of their involvement in the Markovo local indigenous tradition, as I could see as an outsider and ethnographer, these women were sure that they were not familiar with it because of the generation gap. Unlike the traditional healing knowledge of elders and shamans, which was believed in Markovo as being "transmitted from generation to generation", the traditional healing knowledge of these women was not theirs, and their own healing knowledge was not traditional. However, they needed strength and knowledge of their own to protect their children. So, beyond this general resource - the ancestral healing heritage - the women elaborated their own healing abilities, and used all the accessible sources to do that - they recalled the elders' stories (skazki) in which they 
did not believe before, they listened to the advice of newcomers "from mainland", and they were interested in mass culture production.

The healing techniques of Antonina, and some of Nina's, can be described as 'modern' (i.e. contemporary and widely spread), which stands in contrast with the local traditional and shamanic healing complex that remains secret for the outsiders and which was represented in the community by stories about elders and shamans, and usually presupposed the rite (Hakkarainen 2005). As to their life, the only thing that these women shared, as contemporary healers with shamans of the past, was their indigenous (and, consequently, shamanic) origin. The indigenous community as a whole possessed (and each of its members had skills to use) shamanic heritage.

The people of Markovo distinguished between the representations of different types of knowledge among the young and the elders and marked off the living and 'the elders in the past'/'dead in the present' in the community. Usually this continuity becomes actualized in the process of dreaming when ancestral tradition was accessible to the descendants.

\section{DREAMS}

Barbara Tedlock begins her article on dreaming and dream research as follows,

Dreaming is a universal experience, one that individuals may attempt to induce or avoid, remember or forget. From the earliest times dreams and their classification, narration, and interpretation have been of considerable interest to humankind. (Tedlock 1987: 1)

It is difficult to deny that this experience has different meanings in different communities.

Dreams are generally very important for the villagers of Markovo: they serve as evidence of links between the worlds of the living and the dead. While dreaming, one can learn about a child to come, who of the recently dead will "arrive from afar" (dalioko prishel). In their dreams, villagers, as mentioned above, get the ancestral knowledge or the healing skills of their recently dead relatives. Sleep is also an opportunity for the living to help the dead with their being there. In the past, dreaming was a shaman's way to learn about the course of illness and healing - "the shaman slept a bit, and got to know how to cure" (male informant, born in 1932). 
Nowadays, women receive similar knowledge in dreaming and a similar state. ${ }^{13}$ They also get to know whether they have enough knowledge to practice healing - the dreams are messages about these powers from the other world. That is why discussion about dreams seems to form a significant part of the communication inside female communities: women interpret dreams, explain the nature of unclear events that have happened to them in the course of life, and connect local beliefs and modern metaphysical explanations. Dreams are like riddles that should be solved: the motif of (re)cognition is very important in stories about dreams. Dream narratives define women's position in the society; they are important means used by local adult women in the construction of their identity.

It should be stressed that the indigenous narrative tradition of Markovo has inspired a wide spectrum of tales about the wise people and their varying range of special knowledge. People had their individual narrative repertoire, which often represented their or their relatives' life experience, and differed from person to person. Only the social relations between the characters have remained the same: youth did not know how to treat the elders, unfamiliar elders sent illnesses to the youngsters for their wrong behaviour, local elders undid this witchcraft, the recently dead elders helped their children, and so forth. ${ }^{14}$ Dream narratives, as they were recorded in interviews, also did not strictly follow the established narrative forms. ${ }^{15}$ So women had personal repertoire of dream stories, images and plots, and they were closely connected with their biographical particularities (see, e.g., Georges \& Jones 1995). Each of them had their own complex of dream stories to represent their social place and life circumstances: origin, gender, marital status, possession of knowledge, etc. For this article I chose three of them where the influence of mass media was quite evident.

\section{Influences of Blavatsky (Blavatskaya) ${ }^{16}$}

The dream narratives of Nina attract attention because of their obvious connection with esoteric literature and mass culture images. The first story concerns her daughter, who was found to be a diviner. The local people believe that some younger children are able to get such knowledge from spirits with whom they stay in contact. In the dream the woman was informed that her daughter is a person of this kind. This also represents the mother's ability to receive information about the future - although, as it becomes clear from the story, she shows herself unable to accurately interpret this knowledge: 
And me, before I gave birth [to my daughter], before I got pregnant [...] I know, they usually say that fish portends pregnancy. [...] And me, I was catching fish then. First, a huge one. And with three eyes. Scary [fish]. Well, there was a lot of fish there. But why particularly this fish? She almost jumped upon me. And I certainly woke up. And [I] think, o Lord! It's the first time I see a fish with three eyes. Well, and then [my acquaintance] tells me, well, you'll have a three-eyed child. I say, "Lord, what kind of monster will it be?" She says, "Oh, no! [...] She will have the third eye." [...] And after I had this dream, I read this [...] I read Blavatsky. I was just stunned by the coincidence. It's even scary.

The whole narrative shapes the process how Nina was receiving important knowledge about her unusual future child. She was ignorant and although she understood that she was going to have a child, she did not know the most important information about the child. Her older and more experienced friend explained to her the message about 'the third eye', which Nina had first understood literally. But the knowledge about both the traditional and the modern concepts of her outsider friend revealed to her what this actually widely-spread symbol meant. And later she got confirmation to her friend's words in a book by Blavatsky. So, to a listener, in this narrative unfolds a dramatic and a little self-ironic (while her previous ignorance gave rise for a smile) process of receiving, understanding and legitimating of this significant information. The reference to Blavatsky was the final confirmation of the local knowledge (represented by a knowledgeable friend). The story provided above has a vivid and slightly comical nature, yet at the same it reinforces the verity of the statement by incorporating into Nina's personal knowledge the alien symbol of the sacred vision.

The second dream concerns Nina's own abilities, which were tested and confirmed by unknown superhuman forces. This is a dream about a flight to sacred places. In the dreams of these two women, a flight is a usual topic, which allows associating contemporary dream narratives with shamanic practices and the indigenous traditions of the region. ${ }^{17}$ However, in the women's dreams both the system of images and ways of their constructing are not 'traditional', but clearly 'modern'. What particularly attract attention are the extensive picturesque descriptions of the sacred landscape, as if observed from above, from the bird's-eye-view, and scenes of huge subterranean spaces. Such descriptions of long panoramic views and various special effects are more typical of written text rather than of folklore or traditional tales, ${ }^{18}$ representing the shamans' journeys, and are probably influenced by literature, mass media or films: ${ }^{19}$ 
I kept flying, and somebody kept [telling me] something [...] I remember, we kept and kept flying, [and] they say, well, fine, we are going to show you now. But, they say, you should look. And [...] well, as if... [they said] won't you get scared? [...] Well, I was taken to a plateau, this way. How should I say? Here are the rocks. And between these rocks there is, well, ... a flat space. Lots of people there. All. And this plateau, it is like a rock. You look around - [there is] an abyss. And if you look this way - it's rocks raising up, you know. One looks, and the landscape is... how should I put this correctly - gloomy. Such a landscape... Rocks, abysses, and all this... And such thunder clouds, you know [...] And here all of a sudden... among... these thunder clouds get dispersed. And such a sun beam, a strong kind of sun beam, [falls] straight on the rocks. And they suddenly start to turn around. And there is something grandiose there. There are giant men and women standing there. And a statue of some sort. And here they are holding in their hands [...] So I look this way... And nobody sees. [...] and in a month... I came across a book... in a month... a book that I read. And there... no, I took it in the library.

Then she continues:

You see, I was... led in my dream. And then after some time they led me again. Through some labyrinths, you know, it's... Some strange long labyrinths... They led me and led me... and brought me to such round hall. And he says. - See, if you have something... well, I remember, "If you have, here are seven doors for you - you'll find the exit." And I think to myself, "And what is it that I have?"... Now that's it, and they all left. "And, they say, look for it. For, they say, you'll find right away." And I say, "What if I won't find?" - "Well, then you'll stay here." [...] I started... [I] looked... [and I] looked. And then I think, all right, I'll check now, what is it there... There is space there, you know, and one can see a door. So, I found it.

After her success in locating the right door, she came to an unusual place. Here is the description of it:

By and large, there was some kind of a temple. It was, you know, not like our churches, but something like... As if [it was] in a cave. A cave, you know... a huge cave temple. [...] All those Chinese Buddhas... like... all is collected. [...] So I went. I went and I went. And he is calling me inside this statue... The statue, now it opens. [He] takes me in. All right, so I stopped inside there. And there is something written here. Well, hieroglyphs, you know, this and that. And, you see, I was as if locked 
there. And I ask: "What am I going to do here?" - "You should, [he] says, read them. You did find the door, therefore, read!" I say, "Why should I read this? I say, I don't know this language." - "But you should read, since you found the door." [...] Well, and I think to myself, "This way they will bury me alive in this wall, and I won't be able to read them. Because I don't know hieroglyphs." "No-no-no, I won't." They say, "Think, - they say, - think well. You can read them." I say, "No-no-no." [...] "You won't?" - "No, I say, I don't want to." And then it was over. These dreams stopped. [...] And then somehow I got hold of the book by Blavatsky... this Shambhala. I started to read, and I felt somehow uneasy. [...] Because I was just so impressed by these seven doors. When I read that it's true: they have seven doors. Exactly seven doors.

\section{Barabashka ${ }^{20}$ and others}

The dream narratives of Antonina did not have any direct links and references to the esoteric production. They abound in images non-specific to this locality, both secular and religious, such as southern rural landscapes, modern exteriors and interiors, agents of superhuman forces like books of magic, priests, saints, and Jesus, ${ }^{21}$ which are present in mass media. But all of them are congruently included in the main local conceptual system about the social arrangement of a community.

In the following dream story, pictures of everyday reality and modern urban popular images become entangled with the local concept about the revival of the dead. For example, here is the dream that preceded the birth of the narrator's son:

And once the rumour started to circulate in the boarding school - I didn't know about this - that a barabashka appeared in it. [...] [Children say,] "Somebody is beating and beating against... the wardrobe... against the wardrobe door... as if he is playing." "All right, sit here, and I'll go and see." So I enter. Well, there is a wardrobe... and the door is slamming and slamming, slamming and slamming. And I looked like this... looked down - [there is] a very-very little man [there]. Now that I think of it he looked like my [son]. With such narrow eyes, in a fur coat and fur boots. And I started to make cross signs in my dream. I have never in my life done this - I am not even baptized [laughs]. I am making cross signs in my dream. And he is shaking his head at me - don't, and smiles. And I shrugged off - all right, then run to me. And my hands are small... So I stretched out hands, like this. 
In this narrative barabashka is a part of the past indigenous world and takes the place of a master of the domestic space, the ancestor, "old man" (ded) or "neighbour" (sosedka) (see, e.g. Dyachkov 1992: 226-227).

Narratives about healing by dead relatives who function as healers were represented in quite a customary manner:

I had osteochondrosis. Couldn't get up at all, couldn't do anything. And here I dreamt of him [brother]. As if he is approaching from the direction of the river, and we are going to go for berries, in winter to pick berries. So he goes... I know that he is unlike to be there. And he goes up, he goes. "What are you... how do you feel?" - I say, "You see, I feel pain all over there, I can't even raise my hand." - "Well, all right, I'll help you now."

Traditionally local motifs can get contaminated with elements of 'modern' urban practices of séance:

Now we called the ghosts, “...come, Evgenii Petrovich, good evening, say... come to me, cure me." Well... As for me, I felt, you know, as if I was falling asleep [...] This way... [a friend of mine] heard clearly that the door opened, and there was a kind of whiff from him. [He] sat down and wouldn't leave. Then [he] left. Two or three times he came by...

Her own healing techniques were conceptualized in terms of modern esoteric ideas:

I have read that it is possible to unite with the energy of the cosmos... But it is seldom [possible for me]. In childhood the top of the head is open. It was connection with nature. And then I [start to count] - one, two, three, four, five... I imagine that my top of head becomes open, and the energy of the cosmos comes into my organism, cleans my backbone... all that... It happens so that you see it... something like shine is radiating... something looking like a fan or a funnel...

\section{Traditionalism and beyond: two strategies of self-representation}

In Markovo, healing is a very important part of represented tradition. When the people of Markovo tell about it, they exploit two strategies of self-representation: the first one concerns the locality and its past; the second one represents the locality in its modern and global context.

Narratives about traditional healing knowledge and practices relate to people of the past, to powerful elders and shamans. They represent these charac- 
ters as "local subjects, actors who properly belong to a situated community of kin, neighbors, friends and enemies" (Appadurai 1995: 205, emphasis in the original). Indigenous shamanic knowledge is a marker of previous generations who belonged to this particular locality (cf. Vitebsky 1995: 188). It is not downgraded or rejected by the people who live today, and penetrates their everyday reality through dreams.

The healing knowledge and practices which belong to contemporary people are coming from the external world. They are, as usual, modern, associated with urban life, and disseminated by means of mass media for common use. This knowledge unites people of different places, because it is seen as nonspecific and de-territorialized. Dream narratives and stories about contemporary healing practices are products of a new kind of imagination (in contrast to the so-called 'traditional'), which experiences the influence of newspapers, television, new technologies, etc. In that way the present generation of the people of Markovo enlarge their system of references and represent themselves as consumers of urban culture and modern universal values. Living here and now, the villagers are the representatives of the young generation; they are different when compared to their elders. In this sense women who practice healing maintain the same strategy of representation. They are indigenous people whose abilities for healing are supported by their native origin but in comparison with elders they are performers of new practices. Adoption of esoteric mass production is the 'right' of the living people who belong to the modern world.

The two strategies of representation of the community do not work separately from each other. They help villagers to maintain the social equilibrium between the local and the global as a whole. Traditionalist discourse arises when villagers represent their community to the ethnographer as an internally structured social unity which is rooted in the past. At the same time, people living in the village here and now actually try to broaden the local boundaries and widen their local identity. They exploit mass media in order to include themselves into larger socio-cultural structures on the equal ground.

In this sense the people of Markovo try to be users of both local and universal benefits. Communication with the other world is very important for them, and the sacred is perceived as global. So they try to involve a wide range of superhuman forces that would support them, including their dead who belong to a locality, and indeterminate powers from a universal religious 'pool'. This is why it is not at all accidental that images, symbols and terms connected with different major religious traditions and esoteric doctrines emerge in the narratives of the Markovo healing practitioners. These images and symbols are present not only because of their availability in magazines and newspapers, 
but also because of people's social mobility and willingness to accept the external world with its ideas and values.

Narratives cited above restructure the alienated segments from different systems (ideology, vision, language, rhetoric, aesthetic, etc.), such as images from mass media, presentation of supernatural beings, esoteric and environmentalist ideas, generalized Christian and Buddhist images and symbols. These images become intermingled with specific local conceptions and start supporting them. Widely-shared esoteric ideas and practices begin to function in the local network of social interaction based on relationships between the living and the dead.

\section{CONCLUSION}

In the last decades, the information market of Russia has been flooded with various types of so-called 'esoteric literature'. ${ }^{22}$ Interest in this literature in the post-Soviet Russia has been extremely high, and people often explained it by the desire to find spirituality lost during the Soviet time of ideological pressure. ${ }^{23}$

Adherence to esoteric spirituality as a quest for one's roots is usually considered to be characteristic of townspeople ${ }^{24}$ rather than dwellers of small rural and indigenous communities, situated far from big urban centres. The latter are thought to have a specific local tradition isolated from the influence of the modern world, ${ }^{25}$ the expression of some "primordial" spirituality. With regard to the opposition centre v. periphery (with all its properties such as civilized v. primitive, dynamic v. stable, culture v. nature, etc.) (cf. Friedman 1994: 81), esoterism and tradition, as well as their users, are given a particular place in the hierarchy of social space.

This is precisely what happens to Siberian peoples who live in remote Asian territories (cf. Bassin 1991): they are expected to be 'traditional' compared to the dominating social groups of newcomers. Nowadays, peoples of Siberia have started to actively maintain this image. In the wake of a noticeable shift to indigenous life, tradition ceased to be associated with backwardness (cf. Slezkine 1994) and obtained a value of its own. Consequently, traditionalism became a resource for the mobilization of ethnic and local identities. Now people construct their traditions by choosing emblematic cultural entities specific for their particular group and use them for self-representation in opposition to others (e.g., Thomas 1992: 213, 215-216).

However, when travelling of goods, capital, technologies, people, information, ideas, and images all over the world is recognized as a particular feature 
of the contemporary world (see, e.g., Kearney 1995, Appadurai 1996, Hannerz 1996), Siberian indigenous peoples are not isolated from the surrounding world and its information market. Notwithstanding the increased interest to their tradition, spatially localized in a particular community, people consume multinational cultural products, including esoteric literature. Ideas from mystic doctrines get inscribed into the world outlook of the local people and become part of their practices.

The villagers of Markovo also participate in this process. They build an image of their own universe in accordance with the hierarchical model of spatial relations - centre/periphery, correlating with culture/nature or civilized/ savage (see Friedman 1994: 44). The people of Markovo place themselves in the centre and create a periphery of their own - in the tundra and indigenous villages. There the wisdom of elders was born and shamans may exist until now. At the same time, being the centre of their own social space, the Markovo community is situated on the margins of the global world on the large scale not only geographically, but also in the social, economic and political sense. The administrative arrangement and the general public centre/periphery discourse are known here; the local people are aware of evolutional ideology as well as of its hierarchical meaning. So, the image of the distant surrounding world (connected with the state and power whether in Russia or China) has a high degree of prestige in the social and cultural sense. It contains paraphernalia associated with elaborated fine arts, sophisticated literary competence and religious superiority. The people of Markovo are oriented to prestigious social and cultural models. Representing the main label of their local tradition, shamanism, the Markovo villagers include it in the enlarged world context, and at the same time identify themselves through it.

This way, the inhabitants of Markovo overcome the socio-spatial hierarchy and resist isolation and marginalization, and, as a matter of fact, "exotization" as well. They represent their shamanic practices as cultural heritage equal to that of the socially dominating population, the Russians, and sometimes even to that of some exotic countries. In such cases the images of generally known figures of mass culture, like Vladimir Vysotsky (1938-1980), the actor, "the bard" and cult figure of the late Soviet period, or poet Alexander Pushkin (17991837), ${ }^{\mathbf{2 6}}$ are in use. They explain the existence of local shamans and their practices in terms of scientific achievements, compare these with medical practices, and regard these as equal or more advanced. In this way they include themselves into the context of scientific and practical progress. As was shown in this article, women also learn modern esoteric healing practices, which have become a part of the Markovo sphere of life. 
The division of the community into two parts, the elders and the young, is functional in this context. The elders are keepers of the tradition, the young assimilate modern ideas and practices; links between them help to save the community's inner consensus between the old and the new.

\section{NOTES}

1 In 1998 I visited Chukotka as a participant in the project "Creole Communities in Northeast Siberia" with principle investigator Dr. Peter Schweitzer, University of Alaska, Fairbanks, and did my research under the supervision of Nikolai B. Vakhtin. The next year, in 1999, I collected data alone.

2 For a detailed history of the villagers of Markovo and similar groups see Vakhtin, Golovko \& Schweitzer 2004.

${ }^{3}$ It took me a long time to establish a distance between my data on the healing ideas and practices in Markovo and two different traditions fixed in Russian ethnography to interpret them in terms of 'folk medicine' or 'shamanism'. After all I chose the way to see the healing practices of the villagers as a whole cultural system "anchored in particular arrangements of social institutions and patterns of interpersonal interactions" (Kleinman 1980: 24).

${ }^{4}$ Some of them could be found in the retelling by Dyachkov (1992 [1893]), Sokolnikov (1911), Bogoras (1918), some other sources (e.g., Batyanova 2003) and the data collected during my fieldwork (some of the texts with slight editing were used in my thesis).

${ }^{5}$ For a more detailed discussion see the part about witchcraft in my thesis (Hakkarainen 2005).

${ }^{6}$ When people of different ages were talking about themselves, they always defined their status in the indigenous society as 'the youngsters'.

7 The situation resembles one that Tekki Odulok (Nikolai Spiridonov) described in his ethnographic work about the Yukaghir - they could become 'strong' and shamans only after their death (Odulok 1933: 155, Spiridonov 1930: 207). It is understandable because the people of Markovo, notwithstanding their very varied ethnic selfidentification for outsiders, carry on the Yukaghir tradition and conceptual system in many aspects of their life (see Gurvich 1966).

8 The names of all informants have been changed.

9 Dyuna Davitashvili was a popular figure in sphere of alternative medicine in Russia, and was known already in the Soviet times.

10 The girl was 14 and her friend, a young woman, 28. The latter was not married and spent much of her time with teenagers.

${ }^{11}$ With age these games could become a serious matter or entertaiment for adults. Thus Faith Wigzell in her paper presented on 17 November 2008 at the Centre for 
Russian Studies Seminar Series (UCL School of Slavonic and East European Studies), comparing fortune-telling practices in Russia and Britain, took into consideration not only participation in them (in both countries people participate in these practices), but also attitudes (in Britain more people regarded fortune-telling and divination as a form of entertainment).

12 This technique of seeking and getting help from one's dead relatives was quite customary for the inhabitants of this area: ethnographers described it as attacks (pripadki) already a hundred years ago (Sokolnikov 1911: 118, Bogoraz 1910: 8).

${ }^{13}$ I do not wish to discuss the issue of the different 'states of consciousness' at this point.

${ }^{14}$ Elena Sergeevna Novik has written about the fluidity of Siberian materials describing the practices of shamans. That is why it was necessary to find the 'deep structure' of these narratives (Novik 1984: 19). More about narrative genres and about shamans see Novik 1984: 229-231.

${ }^{15}$ For example, in the agrarian tradition of Northwest Russia, where I have also conducted fieldwork over several years, the so-called traditional narrative forms are stricter even within one small community. According to Jackson Lincoln, dreams could be divided into 'individual dreams' and 'culture pattern dreams' (Tedlock 1987: 21).

${ }^{16}$ Elena Petrovna (Gan) Blavatskaya (1831-1891), elsewhere in the world known as Helena Blavatsky, founder of Theosophy and the theosophical Society.

${ }^{17}$ Ethnographic literature on shamans generally describes their symbolic flying experience as an important part of shaman's identity (for example, in phenomenological studies see Eliade 1964: 5, Hultkrantz 1973: 29, Pentikäinen 1997, etc.). However, this motif was not characteristic of the local Markovo narrative tradition about elders and shamans. The neighbouring Chukchi and Yukaghir traditions do not much elaborate on this motif, although in fairy tales different characters very often found them in the other world: (a typical narrative is "The Scabby Shaman" in Bogoras 1899, see also Bogoras 1910, Skazki 1974). It is difficult to say, and I have no record of it, whether the motif of a flight is particularly characteristic of the Markovo women's dreams in the past.

${ }^{18}$ See, e.g., tales on shamans from the neighbouring traditions which discuss dream journeys (Ksenofontov 1992, Stebnitski 1938, Jochelson 1975, Yakutskie skazki 1964, descriptions of shamanic practices, e.g., Novik 1984, etc.). However, Ksenofontov writes about an exception: in a story about shaman's illness he mentioned that his informant was telling him "hardly interesting delirious visions about a journey to America, where there were big boats, and also to China, etc." (Ksenofontov 1992: 173). The researcher probably saw these visions as "hardly interesting" because of the break from traditional ones. Here it is possible to see how the contemporary world and contemporary information, which the researcher was denying, is included in the shamanic practices.

Dmitrii Funk, though on a geographically more distant tradition of Teleuts than the Markovo tradition, argues that the question "how a shaman's journey is conceptualized and how the transmission of shaman's texts happens", which is highly interesting for researchers, cannot be answered by the author because shamanic 
texts are "silent" (Funk 2005: 163). In the Markovo narrative tradition, as I discovered, the ritual segment of communication of elders and shamans with the other world is always secret from outsiders. In other traditions, they could be more or less 'open' for the eyes of strangers (for example, the Yakut). However all of them leave some kind of uncertainty. I suppose that the texts about the shamans' journeys tell us everything they can, including spatial vagueness, even though we would like to know something more. In this spatial and visual uncertainty or, rather, reticence there is a logic of tradition in its own right, which was very well conceptualized by Caroline Humphrey about the Daur tradition: "That some Daurs conceived of 'the other world' not as some separate place, but as unseen aspect of this world, that is, not as existing on any plane, but omnipresent" (Humphrey 1996: 121). The dreams of my female informants in this sense are open for listeners and tell them much more about the beyond, also in terms of contemporary public discourse and imagery possibilities. They could be compared with modern literature on shamanic experience (e.g., Kalweit 1988: 31-47, see also Lindquist 1997: 87-92).

${ }^{19}$ It is interesting that at the time when I visited Markovo, people did not only order films but produced their own 'home videos'. For example, I have one of these, featuring panoramic views from the helicopter.

${ }^{20}$ In the mass media of the 1990s, this name was used for a master of domestic space in a semiserious manner, and in modern folkloristics it is defined as a personage of 'low demonology' in urban folklore (e.g., Ferapontov 2001). Recently it has been recorded also in agrarian traditions (e.g., Zimina 2007: 186).

${ }^{21}$ Cf. for example Lindquist (1997: 87-92).

22 'Esoteric literature', 'esoteric practices' are the names mainly used in press and public discourse.

${ }^{23}$ It seems to me that this interest is presently calming down.

${ }^{24}$ Esoteric culture and ideology of modernization are in connection with each other (see Kearnye 1976).

${ }^{25}$ In this, ethnographers and anthropologists play their part. As far as ethnographic method is based on producing of the exotic Other, and creates an illusion of its isolation from the surrounding social space, it was the isolationist content of ethnography that was seriously criticized (e.g., Gupta \& Ferguson 1992: 6; Appadurai 1988: 37 ; Burawoy 2000). Now the situation is changing. For example, the BOREAS project shows other perspectives in Siberian studies.

${ }^{26}$ It was a suprise and pleasure for me when these two women invited me to a private 'picnic' (on a riverbank in the village) to celebrate the 200th anniversary of Alexander Sergeevich Pushkin on 6 June 1999. 


\section{REFERENCES}

Appadurai, Arjun 1988. Putting Hierarchy in its Place. Cultural Anthropology, Vol. 3, No. 1 (Feb) (Place and Voice in Anthropological Theory), pp. 37-50.

Appadurai, Arjun 1995. The Production of Locality. In: R. Fardon (ed.) Counterworks: Managing the Diversity of Knowledge. London: Routledge, pp. 204-225.

Appadurai, Arjun 1996. Modernity at Large: Cultural Dimensions of Globalization. Minneapolis \& London: University of Minnesota Press.

Bassin, Mark 1991. Inventing Siberia: Visions of the Russian East in the Early Nineteenth Century. The American Historical Review. Vol. 96, No. 3 (June), pp. 763794.

Basso, Keith H. 1996. Wisdom Sits in Places: Landscape and Language among the Western Apache. Albuquerque: University of New Mexico Press.

Batyanova, Elena P. 2005 To Portraits of Siberian Shamans. Polevye issledovanija Instituta etnologii $i$ antropologii 2003 g. Moskva: Nauka, pp. 150-165.

Bogoras, Waldemar [Bogoraz, Vladimir] 1918. Tales of Yukaghir, Lamut, and Russianized Natives of Eastern Siberia. Anthropological Papers of the American Museum of Natural History. New York: Order of the Trustees. Vol. 20, Part 1. Also available at http://books.google.com/books/p/pub-4297897631756504?id= -lCmZEGEMVkC\&dq=isbn:1605060593, last accessed on 1 March 2009.

Bogoras, Waldemar [Bogoraz, Vladimir] 1899. Skazka o chesotochnom shamane. [The Scabby Shaman.] Zhivaia starina. Part 2, pp. 263-270.

Burawoy, Michael 2000. Introduction: Reaching for the Global. In: M. Burawoy (ed.) Global Ethnography: Forces, Connections, and Imaginations in Postmodern World. Berkeley \& Los Angeles: University of California Press, pp. 1-40.

Cherednikova, Maina P. 2002. "Golos detstva iz dal'nei dali...." Igra, magia, mif v detskoi kul'ture. [Game, Magic, Myth in Children's Culture.] Moskva: Labirint.

Dyachkov, Afanasii E. 1992. Anadyrskii krai. [Anadyr Region.] Magadan: Kn. Izd-vo, pp. 163-267.

Eliade, Mircea 1964. Shamanism: Archaic Techniques of Ecstasy. London: Routledge.

Ferapontov, I. E. 2001. Turistskii byt i folklor: Opyt sistemnogo analiza. [Everyday Life and Folklore of Tourists: Attempt at System Analysis.] Ul'anovsk 2001. Available at http://ruthenia.ru/folklore/ferapontov7.htm, last accessed in March 2009.

Friedman, Jonathan 1994. Cultural Identity and Global Process. London \& Thousand Oaks, CA: Sage Publications.

Funk, Dmitrii A. 2005. Miry shamanov i skazitelei. [Shamans' and Narrators' Worlds.] Moskva: Nauka.

Georges, Robert A. \& Jones, Michael Owen 1995. Folklore as Personal Resource. Folkloristics: An Introduction. Part 9. Bloomington \& Indianapolis: Indiana University Press, pp. 269-312.

Gupta, Akhil \& Ferguson, James 1992. Beyond "Culture": Space, Identity, and Politics of Difference. Cultural Anthropology. Vol. 7, No. 1, pp. 6-23.

Gurvich, I. S. 1966. Etnicheskaya istoria Severo-Vostoka Sibiri. [Ethnic History of Northeast of Siberia.] In: Trudy Instituta Etnografii. Novaia seria. Vol. 89. Moskva: Nauka. 
Hakkarainen, Marina 2004. Becoming an Adult: Negotiation of Identities in Markovo Village (Chukotka). Sibirica. Vol. 4, No. 1 (April), pp. 49-62.

Hakkarainen, Marina 2005. Lokal'nye predstavleniya o bolezniah i lechenii (poselok Markovo, Chukotka). [Local Concepts about Illnesses and Healing, Markovo Village, Chukotka).] PHD thesis. St Petersburg.

Hannerz, Ulf 1996. Transnational Connections: Culture, People, Places. London \& New York: Routledge.

Hultkrantz, Åke 1973. A Definition of Shamanism. Temenos. Vol. 9, pp. 25-37.

Humphrey, Caroline \& Onon, Urgunge 1996. Shamans and Elders: Experience, Knowledge, and Power among the Daur Mongols. Oxford: Oxford University Press.

Jochelson, Waldemar 1975. The Yukaghir and the Yuckaghirized Tungus. Memoirs of the American Museum of Natural History. Vol. 13, Nos. 1-3.

Kalweit, Holger 1988. Dreamtime and Inner Space:The World of the Shaman. Boston \& London: Shambhala.

Kearney, Michael 1995. The Local and the Global: The Anthropology of Globalization and Transnationalism. Annual Review of Anthropology. Vol. 24, pp. 547-565.

Kearney, Michael 1976. Review to "On the Margin of the Visible: Sociology, the Esoteric, and the Occult" by Edward A. Tiryakian. Contemporary Religious Movements: A Wiley-Interscience Series. American Anthropologist: New Series, Vol. 78, No. 1, pp. 147-148.

Khudyakov, Ivan A. 1969. Kratkoe opisanie Verkhoyanskogo okruga. [A Brief Description of the Verkhoyansk Region.] Leningrad: Nauka.

Kleinman, Arthur 1980. Patients and Healers in the Context of Culture: An Exploration of the Borderland between Anthropology, Medicine, and Psychiatry. Berkeley, Los Angeles \& London: University of California Press.

Ksenofontov, Gavril V. 1992. Shamanizm. Izbrannye trudy (Publikatsii 1928-1929 gg.). [Shamanism. Collected Works Published in 1928-1929.] Tvorchesko-proizvodstvennaya firma "Sever-Iug".

Lindquist, Galina 2004. Breaking the Waves: Voodoo Magic in the Russian Cultural Ecumene. In: A. -L. Siikala, B. Klein \& S. R. Mathisen (eds.) Creating Diversities: Folklore, Religion and the Politics of Heritage. Helsinki: Finnish Literary Society, pp. 89-106.

Lindquist, Galina 2006. Conjuring Hope: Healing and Magic in Contemporary Russia. New York \& Oxford: Berghahn Books.

Lindquist, Galina 1997. Shamanic Performances on the Urban Scene: Neoshamanism in Contemporary Sweden. (Stockholm Studies in Social Anthropology, 39). Stockholm: Gotab.

Lurie V. F. 1992. Kratkaia antologia folklora mladshikh podrostkov. [Short Anthology of the Folklore of Younger Teenagers.] Shkolnyi byt i folklor. Vol. 1, pp. 5-13.

Merker, Petr 1998. Po sledam pervoprohodtsev. [On Pioneers'Tracks.] Mir Severa. No. 4.

Novik, Elena S. 1984. Obriad i folklor v sibirskom shamanizme: opyt sopostavleniia struktur. [Ritual and Folklore in Siberian Shamanism.] Moskva: Nauka.

Odulok, Tekki [Spiridonov, Nikolai I.] 1933. Na Krainem Severe. [On the North.] OGIZ: Molodaia Gvardiia.

Olsufev, Aleksandr V. 1896. Obshchii ocherk Anadyrskoi okrugi, ekonomicheskogo sostojanija i byta naselenija s kartoi. [The General Outline of the Anadyr District, 
Its Economy and Household.] In: Zapiski Priamurskogo otdela IRGO, Vol. 2, No. 1. St Petersburg.

Pentikäinen, Juha 1997a [1992]. Shamanism as Narrative Performance. In: Shamanism and Culture. Helsinki: Etnika Co., pp. 51-65.

Pentikäinen, Juha 1997b. The Revival of Shamanism in the Contemporary North. In: Shamanism and Culture. Helsinki: Etnika Co., pp. 86-99.

Silnitski, Anton P. 1897. Poezdka na Kamchatku i na r. Anadyr'. [The Voyage to Kamchatka and the Anadyr River.] Zapiski Priamurskogo otdela IRGO. Vol. 2, No. 3. Khabarovsk.

Skazki 1974 = Skazki i mify narodov Chukotki i Kamchatki. [Fairy Tales and Myths of the Chukotka Peoples.] G.A. Menovshchikov (comp.), E.M. Meletinski (ed.). Moskva: Nauka.

Slezkine, Yuri 1994. Arctic Mirrors: Russia and Small Peoples of the North. Ithaca \& London: Cornell University Press.

Sokolnikov, Nikolai P. 1911. Bolezni i rozhdenie cheloveka v sele Markove na Anadyre. [Illnesses and Birth in Markovo Village on Anadyr River.] Etnograficheskoe obozrenie. Vols. 90-91, Nos. 3-4, pp. 71-172.

Spiridonov, Nikolai I. [Odulok, Tekki] 1930. Oduly (Yukaghiry) Kolymskogo okruga. [Oduls (Yukaghir) of Kolym District.] Sovetskii Sever. Nos. 9-12, pp. 166-214.

Stebnitskii, Sergei N. 1938. Nymylanskie (Koryakskie skazki). [The Nymylan (Koryak) Tales.] Leningrad: Khudozhestvennaia literatura.

Tedlock, Barbara 1987. Dreaming and Dream Research. In: B. Tedlock (ed.) Dreaming: Anthropological and Psychological Interpretations. Cambridge: Cambridge University Press, pp. 1-30.

Thomas, Nicholas 1992. The Inversion of Tradition. American Ethnologist. Vol. 19, No. 2 (May), pp. 213-232.

Toporkov Andrey L. 1998. Pikovaia dama v detskom folklore nachala 1980-kh gg. [Queen of Spades in the Early 1980s' Children's Lore.] Russkii shkol'nyi fol'klor: Ot "vyzyvanii" Pikovoi damy do semeinykh rasskazov. [Russian School Lore: From Summoning the Queen of Spades to Family Narratives.] Moskva: Ladomir, pp. $15-55$.

Tugolukov, Vladilen A. 1975. Poezdka k chuvantsam. [The Journey to the Chuvans.] In: Polevye issledovaniya Instituta etnografii 1974 (AN SSSR. Institut Etnografii im. N.N. Miklukho-Maklaia). Moskva: Nauka, pp. 180-189.

Urvantseva, Natalia G. 2005. Arkhetip zerkala v detskoi magii. [Archetype of Mirror in Children's Magic.] Spring School 2005. Mifologia kak sistema. Folklor i postfolklor: struktura, tipologia, semiotika. Available at http://www.ruthenia.ru/folklore/urvantseva1.htm, last accessed in March 2009.

Vakhtin, Nikolai; Golovko, Evgenii \& Schweitzer, Peter 2004. Russkie starozhily Sibiri: Sotsial'nye $i$ simvolicheskie aspekty samosoznaniia. [Russian Old-Believers in Siberia: Social and Symbolic Aspects of Self-Identification.] Moskva: Novoe izd-tvo.

Vitebsky, Piers 1995. From cosmology to environmentalism: Shamanism as local knowledge in a global setting. In: R. Fardon (ed.) Counterworks: Managing the Diversity of Knowledge. London: Routledge, pp. 182-203. 
Yakutskie skazki 1964 = Yakutskie skazki. [Yakut Folk Tales.] Yakutsk: Yakutskoe knizhnoe izd-tvo AN SSSR, Vol. 1.

Zimina, T. A. 2007. Polevye issledovaniia $v$ derevniakh Velskogo raiona, opisannykh $v$ materialakh arkhiva "Etnograficheskoe buro" kniazia V.N. Tenisheva. [Field Research in the Villages of Vel'skii District as Depicted in the Archive Data of "Ethnographic Bureau" of Prince V. N. Tenishev.] Conference materials: Mezhdunarodnaia nauchnaia konferentsiia Polevaia Etnografiia, St Petersburg. 